\title{
Development of Adobe Flash Media in Increasing Learning Interest
}

\author{
Dhia Asy Syafa', Pratiwi Pujiastuti², Deri Anggraini3
}

DOI: $10.35445 /$ alishlah.v13i2.675

\begin{abstract}
Article Info
Abstract

Keywords:

Learning media;

Adobe flash;

Interest in learning,

Children's literary genre

This research aims to develop learning media products based on Adobe Flash in Indonesian Language Courses in the Elementary School Teacher Education Study Program. This research was conducted through four main stages: define, design, develop, and disseminate. This study uses a questionnaire as a data collection instrument, adapting quantitative research methods with a quasiexperimental approach (quasi-experimental) at the implementation stage in this study. The data to be obtained in the study were collected through interviews, questionnaires, and product rating scales. This scale collected data at the product validity stage, small group trials, and primary field trials. The results of the development of learning media products using a 4D development model with seven main components. Based on the results of the feasibility validation obtained in the Expert test and the initial field test, the feasibility of the media and material the value obtained is "very high" or worth testing. Based on these results, Adobe Flash media was tested with the operational test stage, and it is known that the results were obtained at an attractive value of 3.52 in this category, "Very High" or perfect changes in student interest in learning.
\end{abstract}

Kata kunci:

Media pembelajaran;

Adobe flash;

Minat belajar;

Genre sastra Anak

\begin{abstract}
Abstrak
Penelitian ini merupakan penelitian pengembangan yang bertujuan untuk mengembangkan produk media pembelajaran berbasis Adobe Flash pada Mata Kuliah Bahasa Indoneisa di Program Studi Pendidikan Guru Sekolah Dasar. Penelitian ini dilakukan melalui empat model tahapan utama, yaitu define, design, develop dan disseminate. Penelitian ini menggunakan angket sebagai instrumen pengumpulan data. Metode yang digunakan untuk menganalisis data adalah teknik analisis deskriptif kuantitatif yang diungkapkan dalam distribusi skor dan kategori skala penilaian yang telah ditentukan. Hasil pengembangan produk media pembelajara $\mathrm{n}$ menggunakan model pengembangan 4D dengan 7 komponen utama. Berdasarkan hasil validasi kelayakan yang didapat pada uji Ahli dan uji lapangan awal hasil dari kelayakan media dan materi nilai yang didapatkan "sangat tinggi" atau layak diuji cobakan. Berdasarkan hasil tersebut maka media Adobe Flash diuji cobakan dengan tahap ujioperasioanal dan diketahui hasilnya didapatkan pada nilai minat sebesar 3,52 dalam kategori ini "Sangat Tinggi" atau sangat baik perubahan minat belajar mahasiswa.
\end{abstract}

\footnotetext{
${ }^{1}$ Yogyakarta State University, Indonesia

Email: dhiaasy.2020@student.uny.ac.id

${ }^{2}$ Yogyakarta State University, Indonesia

Email: pratiwi@uny.ac.id

3 PGRI University Of Yogyakarta, Indonesia

Email: derianggraini.2020@student.uny.ac.id
} 


\section{INTRODUCTION}

Education is an essential means to improve human resources (HR) quality in ensuring the sustainability of a nation's development (Trisyagil, Ahmadi, \& Kustiono, 2020). In education, humans can realize all aspects of life and develop their potential by changing the way of thinking, thinking, and behaving in life according to the functions and goals of the national education system. Education is also one of the planned efforts in producing the learning process to increase students' potential. Learning is also believed to be a process of attitude in people, groups, or organizations. The low quality of learning at every level of teaching looks for problems experienced by the Indonesian people. Various efforts have been made, including curriculum development, teacher competence, learning management, media use, and more optimal teaching aids (Chilmi, Sina, \& Utami, 2019).

The development of technology today is very beneficial for the advancement of science, especially in education. With the development of technology, teaching becomes more accessible for the community to obtain. Various kinds of electronic media are made to facilitate this mobility. Computer media is one of the facilities that help learn, especially in the delivery of learning material. Computer as a learning medium is used as an interactive multimedia system to be active and carried out using a student progress database (Mayub, 2019). One of the technology products that are considered appropriate to be used as teaching aids.

In supporting the technology education process, communication is needed because it dramatically affects student learning quality and interest; because technology grows along with progress according to its era, teachers are obliged to integrate technology itself (Kodri, 2020). the growth of science is progressing rapidly. In its use, almost various aspects of the structure. One of them is the increasing number of institutions and schools that practice technology or data technology (Lutfi \& Usamah, 2019).

Teaching aids, or learning tools, are all tools to assist educators in carrying out the learning process to become more efficient and effective. Educators need learning media, one of the learning tools in the learning process, to encourage student understanding to increase student achievement. Learning media is very closely related to the use of information technology because of innovative learning media so that the implementation of learning can run optimally. With the help of computers and information technology, it is hoped to increase student interest in learning during the COVID19 (Corona Virus Disease 2019) pandemic engulfing the world. During the COVID-19 pandemic, people have limited space for movement and direct interaction with other people.

In the learning process in this theory class, there is often a lack of understanding of the material given. Students in the class are less able to capture an overview of the material provided by the lecturer, and the delivery of material that seems abstract tends to make students less interested in learning. As a result, students cannot achieve learning objectives and decrease interest in learning.

The interview results with lecturers and several students found that students' interest in learning decreased in the brave condition. For this reason, increasing student interest in learning to do Research and Development (R\&D) by developing Adobe Flash media in Indonesian Language Course Elementary School 1. Adobe Flash is one of the computer software products of the Adobe system (Sukariasih, Sahara, Nursalam, \& Tangang, 2020). Adobe Flash is a device used to create vector images and animations with a user-friendly interface (Saputro, 2016). One of the interactive learning media that utilizes the use of information and communication technology is Adobe Flash. The animation produced by Adobe Flash is in the form of complex animations that are displayed through objects, backgrounds, and display movements that can be created by the user (Darari, 2017). In the initial trial class, which was carried out in class A8-20, the lecture material focused on testing using the tools and media used and testing the press that had been delivered. Meanwhile, in the field trial classes, the learning process emphasizes understanding the concept of the genre of children's literature, both in terms of the nature, characteristics, and genre of children's literature. 
This genre of children's literature is one of the texts or stories that tells about the life experiences of children; children must be in the vortex of the story and at the same time seem to see themselves in it (Nurgiyantoro, 2019). In addition, in the book (Krissandi, Febriyanto, \& et al., 2018), it is said that Children's literature is a form of imaginative creation with exposure to specific languages that describe the fictional world and introduce descriptions and experiences that have specific aesthetic values that children can make. Anak is a work created by children where the language of the story is made as simple and easy to understand to entertain and educate children his age. The goal is also that children's literature is generally to help children in increasing imagination, mastering the meaning of life, and distinguish human personalities. Along with growth according to the times (Linda \& Arianto, 2018).

The previous research has conducted by Wati and Nugraha (2021). Responses from students to learning media assisted by Adobe Flash CS6 got 97\%, with the interpretation criteria "very strong". Likewise, with the research done by (Prasetyo and Ginting 2020), the use of the Thiagarajan $4 \mathrm{D}$ Development model is: Define, Design, Develop, and Disseminate. Able to meet the aspects of Valid, Practical, and Effective, where the third validity result. Before, the research only reached the product feasibility stage, while the current research has advanced the operational phase.

This research is conducted using the 4D model for Indonesian language learning, and there are four development procedures, namely Define, Design, Development, and Disseminate. The students are directed to capture images of the material presented by the lecturer. This activity is essential to increase students' motivation in learning.

\section{METHOD}

The approach used in this study uses the Research and Development (R\&D) model. This study aims to develop Adobe Flash media. According to Borg \& Gallin (Sriwijayanti, Qomariyah, \& Nurma, 2020) is a process used to develop and validate educational products. The product formed is an Adobe Flash-based interactive learning media for university students. The researchers used the research method to develop 4D devices (Four D Model) in this study. The research development model is a 4D model adapted by Thiagarajan (Muthoharoh \& Sakti, 2021) in which 4D has four development procedures, namely Define, Design, Development, and Disseminate. This research was conducted in the 2020/2021 academic year in class A7-20 and class A8-20 semester II of the Elementary School Teacher Education Study Program, Faculty of Teacher Training and Education PGRI University Yogyakarta. The subjects of this study included material and media expert lecturers and students of class A7-20 and class A8-20 with a total of 40 PGSD FKIP UPY students with the collection technique using Google Form. The object of this research is adobe flash professional learning media for the Children's Literature Genre. 


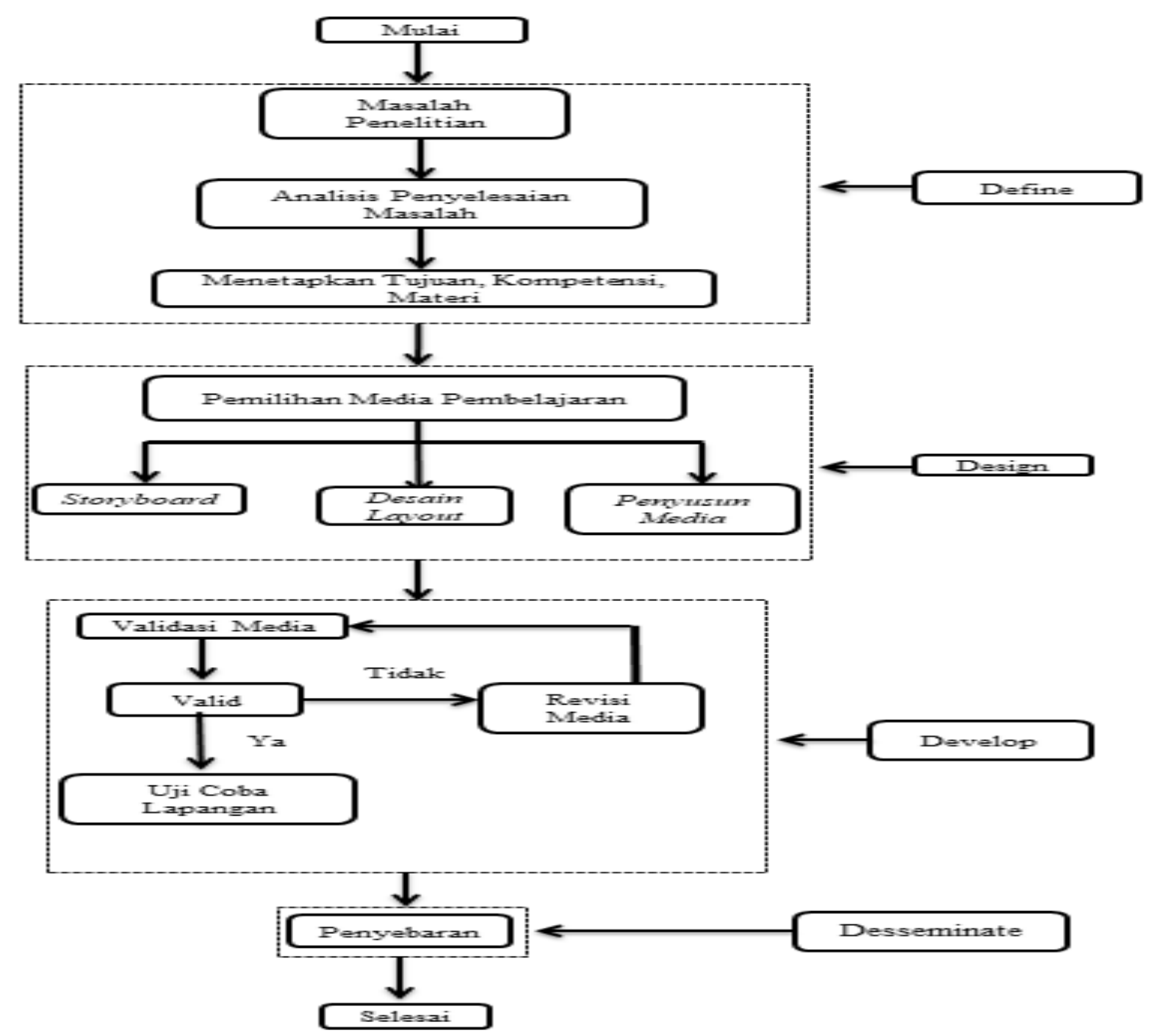

Figure 1. Learning Media Development Research Flow

The implementation stage in this research adopts quantitative research methods with a quasiexperimental approach (quasi-experimental). The data to be obtained in the study were collected through interviews, questionnaires, and a product rating scale. This scale was used as a data collection technique at the product validity stage, initial field trials, and primary field trials. The product rating scale is used during validation, namely the assessment of material experts and media experts. The scale at the initial field trial stage and the main field trial was used to determine lecturers' and students' responses to Adobe Flash media. The product rating scale sheet by material experts and media experts was used to assess Adobe Flash-based interactive learning media feasibility. The scale used is a Likert scale, with a value range of 1-4. These grids cover the appropriateness of the exercises and the materials used. The answer to each instrument item using a Likert scale has a gradation from very positive to very negative. For quantitative analysis, responses can be scored (Sugiyono, 2020). Examples of answers using a Likert scale and their scores: 1) Perfect given a score $=4,2$ ) Good given a score $=3,3$ ) Sufficiently given a score $=2.4$ ) Less given a score $=$ 1

In data collection, the score for each assessment can be obtained, and the average score for each aspect is calculated using the formula:

Information:

$\mathrm{X}=$ average score

$\mathrm{x}=$ Total score 
$\mathrm{n}=$ number of raters

The calculation to obtain the percentage of assessment using the formula: (Sugiyono, 2013:137)

$\mathrm{K}=$ Rating Percentage

$\mathrm{F}=$ Total Number of Respondents' Answers

$\mathrm{AND}=$ Total score Ideal

Table 1. Conversion of Quantitative Data into Qualitative Data

\begin{tabular}{ccc}
\hline Data & Interval & Criteria \\
\hline $\mathrm{X}>\overrightarrow{\mathrm{xi}}+1,8 \times s b_{\mathrm{i}}$ & $\mathrm{X}>3,4$ & Very high \\
$\overrightarrow{\mathrm{i}}+0,6 \times s b i<\mathrm{X} \leq \mathrm{xi}+1,8 \times s b_{\mathrm{i}}$ & $2,8<\mathrm{X} \leq 3,4$ & Tall \\
$\overrightarrow{\mathrm{xi}}-0,6 \times s b i<\mathrm{X} \leq \overrightarrow{\mathrm{xi}}+0,6 \times s b_{\mathrm{i}}$ & $2,2<\mathrm{X} \leq 2,8$ & Enough \\
$\mathrm{X} \leq \mathbf{\mathrm { i }}-0,6 \times s b_{\mathrm{i}}$ & $\mathrm{X} \leq 2,2$ & Not enough \\
\hline
\end{tabular}

\section{FINDINGS AND DISCUSSION}

In the questionnaire given for the media expert test, the material and teacher responses use a Likert scale. The Likert scale measures a person's attitudes, opinions, and perceptions (Sugiyono, 2015: 134). The stages in research and development through the 4D model are as follows:

\section{Definition}

This research begins with knowing the problems that exist in lectures. The researcher analyzes the issues that arise and the current needs related to the learning. The researcher conducted interviews with lecturers of the Indonesian Elementary School 1 subject related to the learning process in the classroom to explore the required information. The information needed is related to media, learning, and student characteristics. Based on interviews with lecturers, one of the obstacles in classroom learning is to condition students in a calm and conducive situation. This was proven when the researchers interviewed the students who seemed less enthusiastic in learning and understanding learning; during learning, students showed an interest in education but were constrained by the learning media that carried out online knowledge. Many students pay less attention to the learning process, and researchers find suitable press to help the online learning process by using Adobe Flash media.

\section{Design}

The researcher processes the results obtained in the previous stage at this design stage, namely the definition stage. The result of this stage is Adobe Flash or the design of learning media along with their descriptions. After Adobe Flash has finished preparing the layout design, it goes directly to the media compiler. The researcher begins to arrange the materials that will be used in the development stage. At this stage, what is done is compiling criteria tests, choosing the form of learning presentation, selecting the media (program/software) that will be used, and compiling media and materials. The preparation of the criteria test includes preparing evaluation questionnaires for material experts and media experts and the preparation of response questionnaires to determine students' responses to learning media.

\section{Development}

At this stage of development, researchers obtained learning media that expert lecturers had validated. Media that has been validated is tested on students. The development phase includes validation by experts and trials. The media that has been developed is then validated. Expert validation tests carried out in this study include the verification of media experts and material experts. The following is the data from the validation results of media experts and content experts on Adobe Flash media.

\section{Media expert validation}

The results of material expert validation obtained a feasibility value of 4.0, which was included in the "Very High" category or deserved to be tested. This is also in line with Andhi Styawan's 
research (2017) that the value is $82.35 \%$ on the results of media expert validation and is very worthy of testing.

2. Validation of material experts

The results of media expert validation obtained a feasibility value of 3.89, which was included in the "Very High" category or deserved to be tested. This is also in line with Andhi Styawan's research (2017) that the value is $94.74 \%$ on the results of material expert validation and is very feasible to be tested.

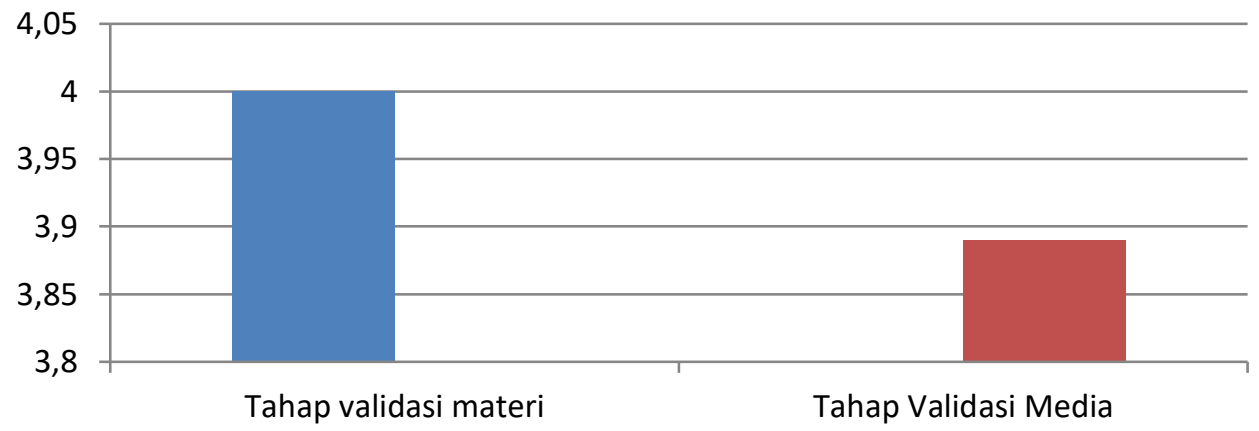

Ahli Materi

Ahli Media

Figure 2 Validation of material and media experts

The following is a form of learning media using Adobe Flash media:

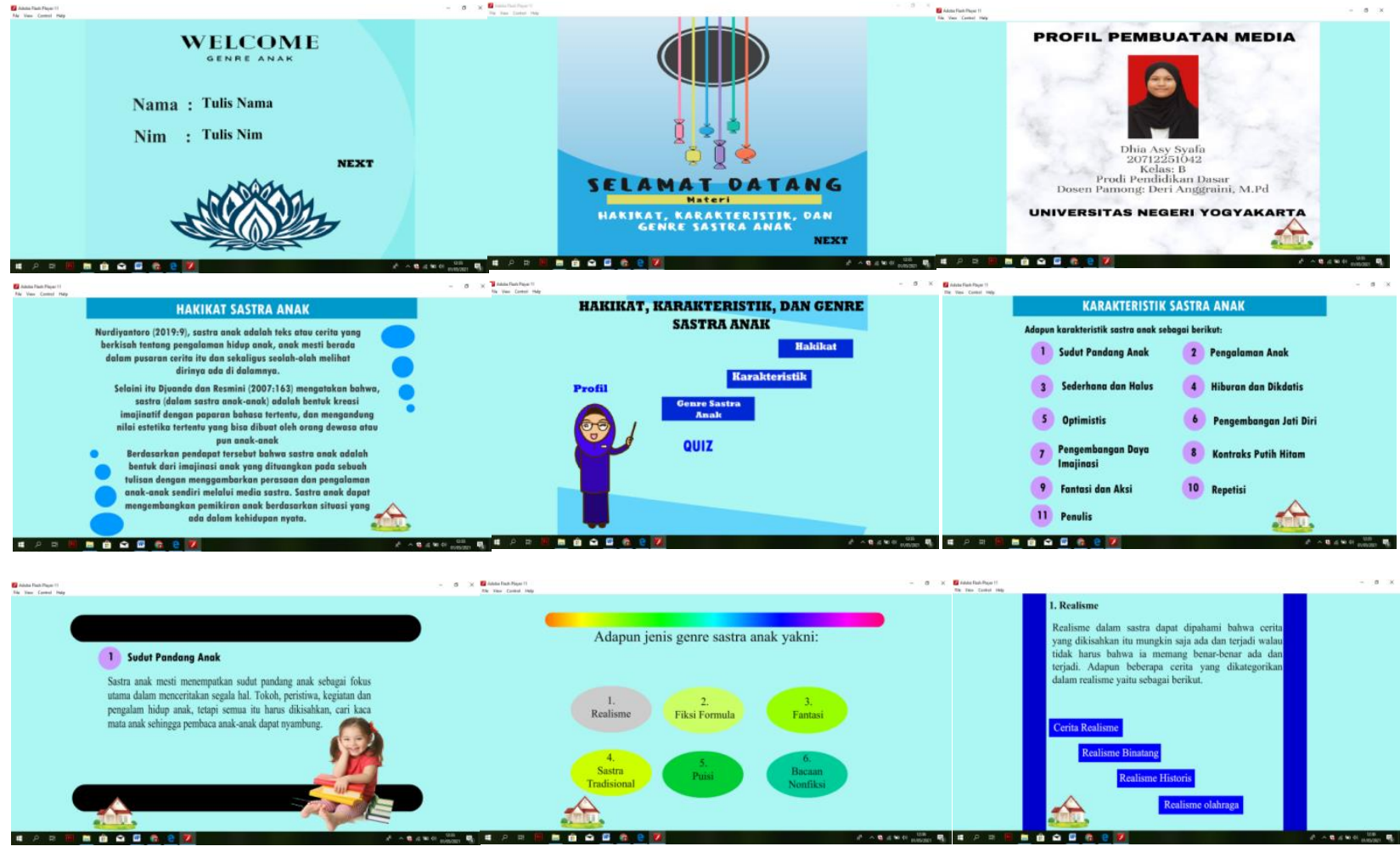

Figure 3. Adobe Flash Learning Media Forms

Based on these results, the material and media are worthy of a trial. After conducting expert validation, it will be continued with small group trials in student responses. Student response data is needed to find out about Adobe Flash media for learning with fewer students. The number of test subjects who participated in the small group trial was nine students from class A8-20. The selection of test subjects was based on the recommendation of the Indonesian language lecturer at SD 1 with the criteria for male and female students who had high, medium, and low academic abilities. The researcher divides students into pairs, then prepares learning media and explains the rules for using 
media. Based on student responses or assessments in the small group trial, they obtained a total score of 587 with an average of 3.43. So, according to the guidelines for converting quantitative data to qualitative data, Adobe Flash media is included in the outstanding category or can be tested in the field.

\section{Dissemination}

The dissemination stage is the last in the development of learning media. At this stage, the Adobe Flash media import is made into an SWF (publish) file by importing this file, how to use it, there is no need to install the application. This media is only distributed via email to each student after being sent via email and distributed to students in class A7-20.

Furthermore, conducting a main field trial using respondents from class A7-20 students at FIP PGSD UPY with 32 students. Student respondents were then asked to respond to the learning media for Children's Literature material by filling in the existing instruments. Based on the responses (responses) in the broader field trial of learning media for Children's Literature material, the results were obtained in the form of an average of 3.47, including very high or already in the category suitable for use learning. This is also in line Styawan's (2017) research that the value is $82.01 \%$ on the results of product feasibility carried out by students, which is very high or can be said to be very suitable for use.

The results of the responses in the broader field trial on student learning interest in learning using Adobe Flash media on Children's Literature material are an average of 3.52, including very high or this media is perfect and able to increase student interest in learning. This is also in line with the research of Ahmad Fahrurrozi Aziz (2015) that using Adobe Flash media can increase student interest in mechanical engineering subjects, obtaining a percentage of $80 \%$ or a score of $78.4 \%$ in the good category. The following is a table of the main field trials that obtained the results of media responses and also interest in using Adobe Flash media.

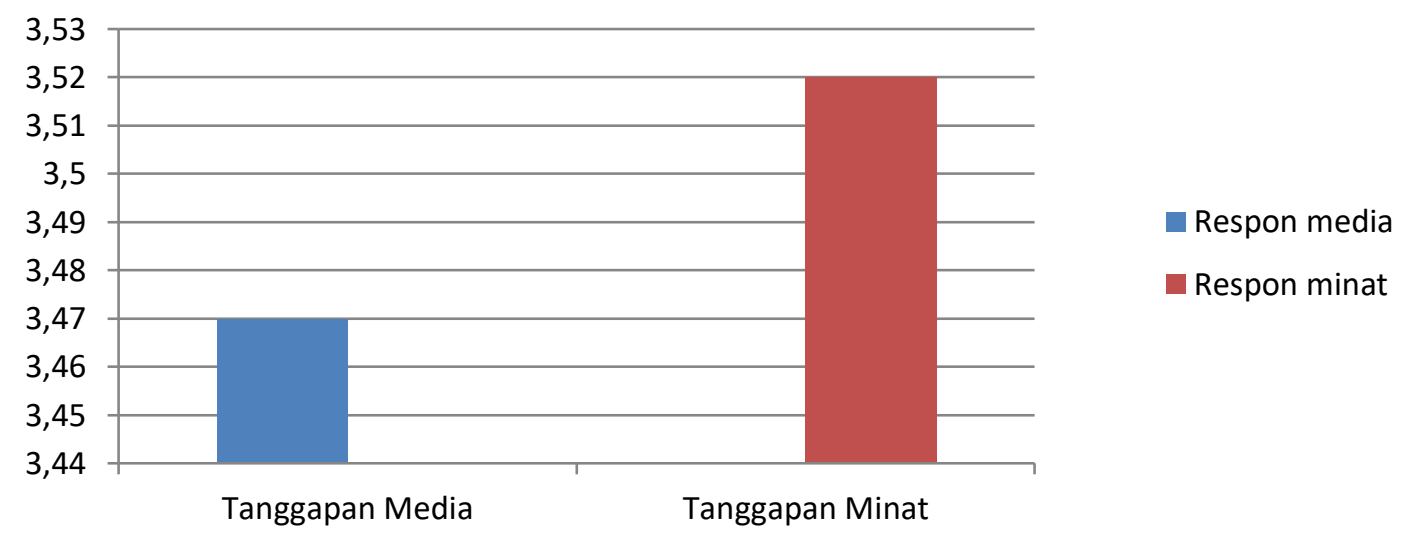

\section{CONCLUSION}

Figure 4. Media and interest responses

Adobe Flash is one of the interactive learning media that utilizes information and communication technology. The effectiveness of students in using Adobe Flash learning media in Indonesian Language courses to increase interest in learning has greatly increased. The results of the feasibility validation obtained in the Expert test and the initial field test, the feasibility of the media and material the value obtained is "Very High" or worth testing. Based on these results, Adobe Flash media was tested with the operational test stage, and it is known that the results were obtained at an attractive value of 3.52 in this category, "Very High" or perfect changes in student interest in learning. This research is still limited to one subject. For further research, can use a sample with a larger scale and be applied to different courses. 


\section{REFERENCES}

Chilmi, F. I., Sina, I., \& Utami, W. B. (2019). The Effectiveness of Course Review Horay Learning Modelwith Adobe Flash Assistance to See Interests Aad Abilities. Mathematics Education Journals, 3 (2) 89-99. https://doi.org/10.22219/mej.v3i2.11050.

Darari, M. B. (2017). Penggunaan Media Adobe Flash pada Pembeljaran Kesebangunan dalam Meningkatkan Kemampuasn Pemecahan Masalah Matematika Siswa SMP Negeri 7 Medan. Jurnal Handayani, 7 (2) 33-41 https://doi.org/10.24114/jh.v7i2.7233.

Kodri, M. N. (2020). Pengembangan Media Pembelajaran Berbasis Android Dengan Menggunakan Adobe Flash Cs6. Jurnal Ilmiah Teknologi Pendidikan, 8 (2) 1-9. https://doi.org/10.24036/et.v8i2.110879.

Krissandi, A. D., Febriyanto, B., \& dkk. (2018). Sastra Anak: Media Pembelajaran Bahasa Anak. Yogyakarta: Bakul Buku Bahasa Indonesia.

Linda, L., \& Arianto, T. (2018). Child Literature Genre Formulation In Waltdisney Animation Movie.Jurnal Basis http://ejournal.upbatam.ac.id/index.php/basis/article/download/776/516.

Lutfi, A. F., \& Usamah, A. (2019). Pengembangan Media Pembelajaran Berbasis Adobe Flash Untuk Mata Pelajaran Fikih Dalam Upaya Meningkatkan Hasil Belajar Siswa. Jurnal Pendidikan Islam, 8 (2) 219-232. http://dx.doi.org/10.30868/ei.v8i2.490.

Mayub, A. (2019). Pembuatan Program Pembelajaran Berbantuan Komputer. Bengkulu: Unit Penerbitan dan Publikasi FKIP Univ. Bengkulu.

Muthoharoh , V., \& Sakti, N. C. (2021). Media Pembelajaran Interakif Menggunakan Adobe Flash CS6 Untuk Pembelajaran IPS Siswa Sekolah Menengah Atas. Jurnal Ilmu Pendidikan, 3 (2) 364 - 375. https://doi.org/10.31004/edukatif.v3i2.315.

Nurgiyantoro, B. (2019). Sastra Anak Pengantar Pemahaman Anak. Yogyakarta: Gadjah Mada University Press.

Saputro, A. (2016). Mudah Membuat Game Advanture Adobe Flash CS6 ActionScript 3.o. Yogyakarta: ANDI.

Sriwijayanti, R. P., Qomariyah, R. S., \& Nurma, I. F. (2020). Pengembangan Media Adobe Flash Berbasis Pakem Di Sekolah Dasar. Jurnal Ilmiah Ilmu pendidikan, 7 (2) 92-105.

Sugiyono. (2020). Metode Penelitian Kuantitatif, Kualitatif dan R\&D. Bandung: Alfabet.

Sukariasih, L., Sahara, L., Nursalam, L. O., \& Tahang, L. (2020). Pengembangan Mutimedia Pembelajaran IPA Terpadu Berbasis Adobe Flash Profesional Cs4 Pada Materi Zat Padat Di Alam. Jurnal Dedikasi Pendidikan, 4 (2) 289-304.

Trisyagil , Ahmadi , F., \& Kustiono. (2020). The Development of Flash-Based Media in Project Based Learning for English Subject to Increase Students' Motivation and Achievement at Senior High School. Innovative Journal of Curriculum and Educational Technology, 9 (2) 48 - 56. https://doi.or/10.15294/ijcet.v9i2.36301 .

Prasetyo, Gihari Eko , and Nurlia Ginting. "Pengembangan Media Pembelajaran Menggunakan Metode Adobe Flash Dengan Menggunakan Model 4-D Tentang Kearifan Lokal Budaya Melayu Langkat Tahun Ajaran 2019/2020." Jurnal Sintaksis, 2020: 2 (1) 93-103.

Wati, Luluk Indah, and Jaka Nugraha. "Pengembangan Media Pembelajaran Interaktif Berbantuan Adobe Flash Cs6 Pada Mata Pelajaran Teknologi Perkantoran di Kelas X OTKP SMK Negeri 1 Lamongan." Jurnal Pendidiikan Administrasi Perkantoran (JPAP), $2021: 9$ (1) 65-76. 